\title{
REVIEW
}

\section{Therapeutic potential of Cymbopogon schoenanthus (L.) developed into nanoparticle technology}

\author{
Lutfi Chabib ${ }^{1,2}$, Adnan Muhammad Uno J Hidayat ${ }^{2}$, A.M. Bagas Trianloka², Muhammad Iqbal Pangestu², \\ Arman Suryani ${ }^{2}$, Yulianto ${ }^{1,2}$ \\ ${ }^{1}$ Department of Pharmacy, Islamic University of Indonesia, Kaliurang Km. 14.5, Yogyakarta, 55584, Indonesia \\ 2Professional Pharmacy Education Program, Islamic University of Indonesia, Kaliurang Km. 14.5, Yogyakarta, 55584, Indonesia
}

\author{
Keywords \\ Cymbopogon schoenanthus (L.) \\ Essential oil \\ Nanotechnology \\ Correspondence \\ Yulianto \\ Professional Pharmacy Education Program \\ Islamic University of Indonesia \\ Yogyakarta 55584 \\ Indonesia \\ yulianto@uii.ac.id
}

\begin{abstract}
Introduction: One of plants that may have therapeutic potential is the Cymbopogon schoenanthus (L.) Spreng, also known as camel grass. Aim: This review aims to investigate and gather comprehensive information about camel grass plants and their potential to be developed into a nanotechnology drug delivery system. Methods: This review examined a variety of online literature. Results: It was found that camel grass contains essential oil such as piperitone. Piperitone is efficacious as an antioxidant, antimicrobial and anti-inflammatory, in addition to other properties. The development of camel grass essential oil into lipid-based nanotechnology preparations can improve its bioavailability, solubility, and stability, thereby improving its potential effectiveness.
\end{abstract}

\section{Introduction}

Cymbopogon schoenanthus (L.) Spreng is a natural herb that grows in tropical regions such as northern and western Africa, the Arabian desert, and Egypt. This plant is also known as "Izkhir" in Arabic, "El bekhirai" in Tunisian, and "Tsabre" in North African. Cymbopogon schoenanthus (L.) Spreng tends to grow in dry places such as the desert and is often used for camel feed, so it is also known as "camel grass" (Burkill \& Dalziel, 1985; IUCN, 2005). In addition, this plant is also found at an altitude of 2000 meters or more in the province of Kiman, Iran (Amina et al., 2013).

Camel grass is shaped like a typical grass with a height of $60-90 \mathrm{~cm}$ (Figure 1). It grows in dry areas away from water sources. Camel grass has a distinctive taste and aroma due to its essential oils (Ben Othman et al., 2013). So, it is often used as a flavouring agent, fragrance, cosmetics, or perfume (Amina et al., 2013; Avoseh et al., 2015). The classification of camel grass plants is explained as follows (ITIS, 2020) :

$\begin{array}{ll}\text { Kingdom } & \text { : Plantae } \\ \text { Division } & \text { : Tracheophyta } \\ \text { Class } & \text { : Magnoliopsida } \\ \text { Order } & \text { : Poales } \\ \text { Family } & \text { : Poaceae } \\ \text { Genus } & \text { : Cymbopogon } \\ \text { Species } & \text { : Cymbopogon schoenanthus (L.) Spreng. }\end{array}$

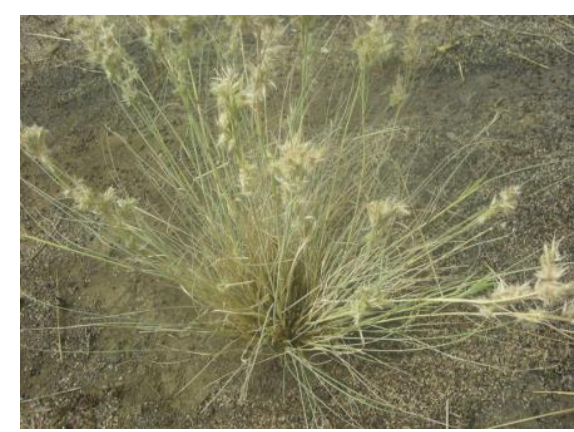

Figure 1: Cymbopogon schoenanthus (L.) Spreng (African Plants, 2020) 
Cymbopogon schoenanthus (L.) Spreng contains essential oil, which is a typical source of monoterpenes such as piperitone and several other components known as intermedeol, $\delta$-2-carene, and elemol (Pavlovic et al., 2017). Based on previous research, the chemical compounds of camel grass essential oil is efficacious as an antioxidant, antiacetylcholinesterase, antimicrobial, anti-inflammatory, spasmolytic, and contains other properties; Khadri et al., 2010; Pavlovic et al., 2017). However, currently, there are no articles that summarize specifically the content of chemical compounds, potential efficacy and benefits of camel grass. Therefore, this review article aims to collect comprehensive information about the efficacy of Cymbopogon schoenanthus (L.) Spreng and its potential development into pharmaceutical nanotechnology.

\section{Methods}

The authors utilised various online databases to carry out a literature review, such as PubMed, ScienceDirect, Research Gate, and Google Scholar. The search keywords used were Cymbopogon schoenanthus (L.) Spreng, camel grass, chemical compounds, therapeutic activity, and nanotechnology. The inclusion criteria were 1) published national and international articles; 2) English language; and 3) Indonesian language. The exclusion criteria were 1) unpublished articles; and 2) articles with invalid sources. The authors found and screened 35 references using the inclusion and exclusion criteria. The authors then used 27 references selected by the inclusion criteria to be reviewed in this article.

\section{Results and discussion}

\section{Chemical compounds of camel grass}

Camel grass has many chemical compounds. A study conducted by Pavlovic and the authors (2017) using camel grass from Sudan, showed in GC-MS testing that there were up to 45 different components in essential oils from camel grass. The flower and stem of the plant are used with camel grass flowers containing essential oils of $1.9-2.0 \%(\mathrm{v} / \mathrm{w})$ compared to the stems of 0.2 $0.6 \%(\mathrm{v} / \mathrm{w})$. Piperitone makes up 47.7 to $71.5 \%$ of camel grass essential oil (Figure 2). Other compounds in camel grass include intermedeol (6.1-17.4\%), $\delta$-2carene (4.5-10.0\%) and elemol (5.2-9.0\%) (Pavlovic et al., 2017). Studies on camel grass from Algeria also obtained similar results showing a compound composition of piperitone (63.3\%), eudesmol (9.3\%), $\delta$ 2-carene (4.9\%), and elemol (6.9\%) (Naima et al., 2016). (a)<smiles>CC1=CC(=O)[C@H](C)CC1</smiles>

(b)<smiles>C=C(C)[C]1CC=C(C)CC1</smiles>

Figure 2: Chemical structure of piperitone (a) and limonene (b) (Ganjewala, 2009)

Studies of camel grass harvested from Tunisia in JuneJuly 2006 found that it contained 30 different components dominated by limonene (10.5-27.3\%), $\beta$ phellandrene (8.2-16.3\%), $\delta$-terpinene (4.3-21.2\%) and $\alpha$-terpineol (6.8-11.7\%) (Khadri et al., 2008). Hence, this shows that chemical compounds obtained from camel grass can be influenced by geographical conditions, seasons, and time of harvest (Khadri et al., 2008; Ganjewala, 2009; Naima et al., 2016; Pavlovic et al., 2017).

\section{Pharmacological activity}

\section{Antioxidant}

Antioxidant activity was tested by using the DPPH test method. This test illustrates the ability of the camel grass essential oil to capture free radicals from 2,2diphenyl-1-picryl hydrazyl (DPPH) by releasing hydrogen atoms or electrons. The study conducted by Khadri and authors (2010) obtained IC 50 values, ranging from $12.6 \pm 3.4 \mu \mathrm{g} / \mathrm{mL}$ to $26.4 \pm 6.8 \mu \mathrm{g} / \mathrm{mL}$. Camel grass was harvested from 3 different types of places i.e. desert, mountain, and plant culture (Khadri et al., 2010). Due to its antioxidant ability, camel grass can be utilized in the food industry as a substitute for synthetic antioxidants (Khadri et al., 2008).

\section{Anti-acetylcholinesterase}

Acetylcholinesterase (AChE) is an enzyme that plays a role in inhibiting the transmission of nerve impulses in cholinergic synapses by hydrolyzing acetylcholine. When acetylcholine levels in the body are too low, it can result in neurological diseases such as Alzheimer, dementia, ataxia, and myasthenia gravis. The inhibitory activity of acetylcholinesterase can be found in many plants (Mukherjee et al., 2007). Cymbopogon schoenanthus (L.) Spreng has been shown to have moderate anti-acetylcholinesterase activity with $\mathrm{IC}_{50}$ values between $0.23 \mathrm{mg} / \mathrm{mL}$ to $0.75 \mathrm{mg} / \mathrm{mL}$ (Khadri et al., 2010). 


\section{Antimicrobial}

A study tested the antimicrobial activity of essential oils from camel grass against bacteria of the streptococci species, namely $S$. mutans and $S$. sobrinus, which commonly cause dental caries. The results obtained showed that its antimicrobial activity effectively inhibits the growth of $S$. sobrinus bacteria at concentrations of $4 \mathrm{mg} / \mathrm{mL}$ and $8 \mathrm{mg} / \mathrm{mL}$ whilebacterial growth inhibition activity for $S$. mutants was seen at a concentration of $32 \mathrm{mg} / \mathrm{mL}$ (Khadri et al., 2010).

Cymbopogon schoenanthus (L.) Spreng also registered strong antimicrobial activity in studies on inhibitory zonesagainst Enterococcus faecium (21 $\pm 1.4 \mathrm{~mm})$, Staphylococcus aureus (19.5 $\pm 0.7 \mathrm{~mm})$, Escherichia coli (15 $\pm 1.4 \mathrm{~mm})$, Salmonella typhimurium $(10.5 \pm 0.7 \mathrm{~mm})$, Streptococcus agalactiae $(12.75 \pm 0.3 \mathrm{~mm})$, and Candida albicans (12 $\pm 1.4 \mathrm{~mm}$ ) (Naima et al., 2016).

\section{Anti-inflammatory}

Anti-inflammatory activity can be found in camel grass essential oil, according to a study that conducted antiinflammatory tests through carrageenan-tests on mice. Camel grass essential oils were administered intraperitoneally and found to significantly reduce paw oedema in doses of 50,100 , and $200 \mathrm{mg} / \mathrm{kg}$, proving that camel grass essential oil has an effective antiinflammatory effect in the acute inflammation phase (Talaei et al., 2019). Other studies have shown that camel grass essential oil can inhibit the release of Nitric oxide (NO), which is an inflammatory mediator in RAW 264.7 cells, while IC 50 test results show concentration values between $1.32 \pm 0.17 \mathrm{mg} / \mathrm{mL}$ to $1.38 \pm 0.04 \mathrm{mg} / \mathrm{mL}$ ( Gomes et al., 2017; Sukaboon et al., 2019).

\section{Spasmolytic activity}

A study revealed that Cymbopogon schoenanthus (L.) Spreng essential oil has spasmolytic activity in the concentration range of $10-130 \mu \mathrm{g} / \mathrm{mL}$. Testing was done by inducing acetylcholine in mice to observe effectiveness in inhibiting spontaneous contractions in rat ileum. The strongest spasmolytic activity was seen at a concentration of $130 \mu \mathrm{g} / \mathrm{mL}$, which is equivalent to the maximum relaxant effect of atropine at a concentration of $6.4 \mu \mathrm{M}$ (Pavlovic et al., 2017). Another experiment method was also carried out to induce Potassium Chloride ( $\mathrm{KCl})(80 \mathrm{mM})$, which causes tonic contractions. Camel grass essential oil was found to inhibit the contraction effect of $\mathrm{KCl}$ by up to $19.67 \pm 20.26 \%$ at a concentration of $30 \mu \mathrm{g} / \mathrm{mL}$ (Pavlovic et al., 2017).

\section{Anti-stress activity}

The anti-stress activity of camel grass essential oil was tested on SH-SY5Y human cells and heat-stressed HSP47-transformed cells. It was also tested in mice using the tail suspension test (TST) and forced swimming test (FST) methods. TST and FST tests are used as these are methods that most closely resemble the condition of depression in humans (Ben Othman et al., 2013). Camel grass essential oil was found to protect these cells from stress-related disruption. In experiments using mice, camel grass essential oils at doses of 100 and $200 \mathrm{mg} / \mathrm{kg}$ administered orally were able to reduce the immobility time in the TST and FST tests indicating anti-stress activity.

\section{Anthelmintic activity}

Cymbopogon schoenanthus (L.) Spreng has a terpenoid compound that can inhibit the parasite growth phase. It has shown good anthelmintic activity as evidenced by four different tests: 1) Egg hatching assay (EHA) test; 2) larval development assay (LDA); 3) larval feeding inhibition assay (LFIA); and 4) larval escheatment assay (LEA) and in which the $L C_{50}$ values obtained were 0.045 $\mathrm{mg} / \mathrm{mL}, 0.063 \mathrm{mg} / \mathrm{mL}, 0.009 \mathrm{mg} / \mathrm{mL}$, and $24.66 \mathrm{mg} / \mathrm{mL}$, respectively. Cymbopogon schoenanthus (L.) Spreng is the best candidate for nematode control when compared to Cymbopogon martinii and Mentha piperita in the same study (Katiki et al., 2011).

\section{Insecticidal activity}

The piperitone component in camel grass is known to inhibit the growth of neonatal eggs and larvae of Callosobruchus maculatus, whereas camel grass essential oil is also found to reduce the fertility of $C$. maculatus females by affecting the number of eggs produced (Ketoh et al., 2006; Aous et al., 2019).

\section{Nanotechnology application}

The use of nanotechnology in pharmaceutical preparations is able to cover the deficiencies of active substances, especially those derived from herbs or natural ingredients. Essential oils have an oil base, so they are more difficult to absorb in the body and have low bioavailability. Traditional processing of natural ingredients also usually requires a greater number of doses (Mukherjee et al., 2015). Nanotechnology is divided into several dosage forms depending on the material used in the formulation and the method used for manufacturing. Generally, the nanotechnology form has a particle size between $20-200 \mathrm{~nm}$, therefore it is often also referred to as nanoparticles. This preparation can improve bioavailability, solubility, and poor stability. This preparation also helps deliver active substances through cell membranes to reach action sites (Chabib et al., 2020). 
A study conducted by Ujilestari et al. was able to formulate essential oils from Cymbopogon citratus (lemongrass) in the form of spherical-shaped particles in self nano-emulsion drug delivery systems (SNEDDS). The characterization results showed the lemongrass SNEDDS preparation had a particle size of $20.7 \mathrm{~nm}$ and a polydispersity index (PI) of 0.378 (Tri Ujilestari et al., 2018). Further studies also carried out an antibacterial test of Cymbopogon citratus in SNEDDS preparations and proved its effectiveness in inhibiting the growth of Escherichia coli, Salmonella thyphimurium, and Lactobacillus acidophilus bacteria (T Ujilestari et al., 2019).

Another study conducted by Manju and the authors (2016), successfully formed a gold nanoparticle preparation from the essential oil of Nigella sativa. Its particle size range was $15.6-28.4 \mathrm{~nm}$ in a spherical, triangle, and hexagonal shapes. Nigella sativa SNEDDS was able to inhibit the growth of Staphylococcus aureus $(16 \mathrm{~mm})$ and Vibrio harveyii $(5 \mathrm{~mm})$ at a concentration of $10 \mu \mathrm{g} / \mathrm{mL}$. In the dosage range of $20-80 \mu \mathrm{g} / \mathrm{mL}$, it was also shown to inhibit the biofilms of $S$. aureus and $V$. harveyii formed. In anti-cancer testing on A549 lung cancer cells, gold nanoparticles were able to inhibit the growth of cancer cells with $\mathrm{IC}_{50}$ values of $5-50 \mu \mathrm{g} / \mathrm{mL}$ (Manju et al., 2016).

The results of the two studies above suggest that it is possible to develop camel grass essential oils into nanotechnology drug delivery systems. It is assumed that camel grass has the same essential oil profile as other plants, which can be developed into the nanoparticle dosage form.

\section{Conclusion}

Cymbopogon schoenanthus (L.) Spreng or camel grass is one of the medicinal plants mentioned in the AlQuran and Hadith, which contains essential oils and substances like piperitone, intermedeol, $\delta$-2-carene, and elemol. It is useful pharmacologically, containing antioxidant, anti-acetylcholinesterase, antimicrobial, anti-inflammatory, spasmolytic, anti-stress, anthelmintic, and insecticidal properties. Essential oils from Cymbopogon schoenanthus (L.) Spreng also has the potential to be developed into a nanotechnology drug delivery system.

\section{Acknowledgement}

The authors would like to thank the Nanopharmacy Research Center, Laboratory of Pharmaceutical Technology, Department of Pharmacy, Islamic University of Indonesia, and others who supported the publication of this article published. The authors declare no conflict of interest.

\section{References:}

African Plants. (2020). Picture of Cymbopogon schoenanthus (L.) Spreng (online). Available at: https://www.aficanplants.senckenberg.de

Amina, R.M., Aliero, B.L., \& Gumi, A.M. (2013). Phytochemical screening and oil yield of a potential herb, camel grass (Cymbopogon schoenanthus Spreng.). Central European Journal of Exerimental Biology, 2(3), 15-19.

Aous, W., Benchabane, O., Outaleb, T., Hazzit, M., Mouhouche, F., Yekkour, A., \& Baaliouamer, A. (2019). Essential oils of Cymbopogon schoenanthus (L.) Spreng. From Algerian Sahara: Chemical variability, antioxidant, antimicrobial and insecticidal properties. Journal of Essential Oil Research, 31(6), 562-572. https://doi.org/10.1080/10412905.2019.1612790

Avoseh, O., Oyedeji, O., Rungqu, P., Nkeh-Chungag, B., \& Oyedeji, A. (2015). Cymbopogon Species; Ethnopharmacology, Phytochemistry and the Pharmacological Importance. Molecules, 20(5), 7438-7453. https://doi.org/10.3390/molecules20057438

Ben Othman, M., Han, J., El Omri, A., Ksouri, R., Neffati, M., \& Isoda, H. (2013). Antistress Effects of the Ethanolic Extract from Cymbopogon schoenanthus Growing Wild in Tunisia. Evidence-Based Complementary and Alternative Medicine, 19. https://doi.org/10.1155/2013/737401

Burkill, H.M., \& Dalziel, J.M. (1985). The Useful Plants of West Tropical Africa, Royal Botanical Gardens, Kew, London, 2, 439

Chabib, L., Trianloka, A.M.B., Hidayat, A.M.U.J., Awaluddin, R., \& Firmansyah, F. (2020). Potential Tropical Fruits to Aid Sports Performance and its Prospect to be Developed into Nano supplement. IOP Conference Series: Earth and Environmental Science. 448, 012019. https://doi.org/10.1088/1755-1315/448/1/012019

Ganjewala, D. (2009). Cymbopogon essential oils: Chemical compositions and bioactivities. International Journal of Essential Oil Therapeutics, 11

Gomes, E., Bernardo, J., Barbosa, M., Andrade, P.B., Valentão, P., \& Lopes, G. (2017). Ethnopharmacological use of Cymbopogon citratus (DC.) Stapf and Cymbopogon schoenanthus (L.) Spreng.: Anti-inflammatory potential of phenol-rich extracts: PS129. Porto Biomedical Journal, 2(5), 216-217. https://doi.org/10.1016/j.pbj.2017.07.099

ITIS. (2020). Taxonomy of Cymbopogon schoenanthus (L.) Spreng form the Integrated Taxonomic Information System (ITIS). Available at: http://www.itis.gov IUCN. (2005). A guide to medicinal plants in North Africa, ISBN: 2, 8317-0893-1, 256p

Katiki, L.M., Chagas, A.C.S., Bizzo, H.R., Ferreira, J.F.S., \& Amarante, A.F.T. (2011). Anthelmintic activity of Cymbopogon martinii, Cymbopogon schoenanthus and Mentha piperita essential oils evaluated in four different in vitro tests. Veterinary Parasitology, 183(1-2), 103-108. https://doi.org/10.1016/j.vetpar.2011.07.001 
Ketoh, G.K., Koumaglo, H.K., Glitho, I.A., \& Huignard, J. (2006). Comparative effects of Cymbopogon schoenanthus essential oil and piperitone on Callosobruchus maculatus development. Fitoterapia, 77(7-8), 506-510. https://doi.org/10.1016/j.fitote.2006.05.031

Khadri, A., Neffati, M., Smiti, S., Falé, P., Lino, A.R.L., Serralheiro, M.L.M., \& Araújo, M.E.M. (2010). Antioxidant, antiacetylcholinesterase and antimicrobial activities of Cymbopogon schoenanthus L. Spreng (lemon grass) from Tunisia. LWT - Food Science and Technology, 43(2), 331-336. https://doi.org/10.1016/j.Iwt.2009.08.004

Khadri, A., Serralheiro, M.L.M., Nogueira, J.M.F., Neffati, M., Smiti, S., \& Araújo, M.E.M. (2008). Antioxidant and antiacetylcholinesterase activities of essential oils from Cymbopogon schoenanthus L. Spreng. Determination of chemical composition by GC-mass spectrometry and $13 \mathrm{C}$ NMR. Food Chemistry, 109(3), 630-637. https://doi.org/10.1016/j.foodchem.2007.12.070

Manju, S., Malaikozhundan, B., Vijayakumar, S., Shanthi, S., Jaishabanu, A., Ekambaram, P., \& Vaseeharan, B. (2016). Antibacterial, antibiofilm and cytotoxic effects of Nigella sativa essential oil coated gold nanoparticles. Microbial Pathogenesis, 91, 129-135. https://doi.org/10.1016/j.micpath.2015.11.021

Mukherjee, P.K., Harwansh, R.K., \& Bhattacharyya, S. (2015). Bioavailability of Herbal Products. In Evidence-Based Validation of Herbal Medicine (pp. 217-245). Elsevier. https://doi.org/10.1016/B978-0-12-800874-4.00010-6

Mukherjee, P.K., Kumar, V., Mal, M., \& Houghton, P.J. (2007). Acetylcholinesterase inhibitors from plants. Phytomedicine, 14(4), 289-300.

https://doi.org/10.1016/j.phymed.2007.02.002

Naima, H., Mahfoud, H.M., Farah, R., \& Alia, T. (2016). Antimicrobial and antioxidant activities of Cymbopogon schoenanthus (L.) spreng. Essential oil, growing in IlliziAlgeria. Journal of Medicinal Plants Research, 10(14), 188194. https://doi.org/10.5897/JMPR2015.5985

Pavlovic, I., Omar, E., Drobac, M., Radenkovic, M., Brankovic, S., \& Kovacevic, N. (2017). Chemical composition and spasmolytic activity of Cymbopogon schoenanthus (L.) Spreng. (Poaceae) essential oil from Sudan. Archives of Biological Sciences, 69(3), 409-415. https://doi.org/10.2298/ABS160506113P

Sukaboon, R., Karnchanatat, A., Sangtanoo, P., Saisavoey, T., Pattaratanakun, A., Asawanonda, P., Reamtong, O., \& Inkanuwat, A. (2019). Nitric Oxide Synthesis Inhibition and Anti-Inflammatory Effect of Polypeptide Isolated from Chicken Feather Meal in Lipopolysaccharide-Stimulated RAW 264.7 Macrophages. Food Technology and Biotechnology, 57(2), 200-212. https://doi.org/10.17113/ftb.57.02.19.5964

Talaei, M.G., Mousavi, Z., \& Jahandideh, M. (2019). AntiInflammatory Activity of Cymbopogon schoenanthus Essential Oil in Animal Models. 6(3), 8

Ujilestari, T, Martien, R., Ariyadi, B., Dono, N.D., \& Zuprizal. (2019). Antibacterial effects of essential oils of Cymbopogon citratus and Amomum compactum under selfnanoemulsifying drug delivery system (SNEDDS). IOP
Conference Series: Earth and Environmental Science, 387, 012071. https://doi.org/10.1088/1755-1315/387/1/012071

Ujilestari, Tri, Danar Dono, N., Ariyadi, B., Martien, R., \& Zuprizal, Z. (2018). Formulation and characterization of selfnano emulsifying drug delivery systems of lemongrass (cymbopogon citratus) essential oil. Malaysian Journal of Fundamental and Applied Sciences, 14(3), 360-363. https://doi.org/10.11113/mjfas.v14n3.1070 